MARTA DORENDA

Wydział Humanistyczny UMK

\title{
Polityka na Onecie
}

M inęło ponad 30 lat od momentu, w którym Ken Olson, legenda amerykańskiego przemysłu informatycznego, stwierdził, że „,nie widzi powodu, dla którego ludzie chcieliby mieć komputer w domu". Kilkanaście lat później William Henry Gates III uznał Internet za „niepoważne zjawisko”. Obecnie z tej globalnej sieci teleinformatycznej korzysta ponad miliard osób na świecie ${ }^{1}$. Co więcej, jej używanie nie ogranicza się do biernego odbioru podawanych treści, lecz polega na ich aktywnym wspóttworzeniu. Twórczość ta nie zawsze jest abstrakcyjna - najczęściej przejawy życia w światach wirtualnych są odzwierciedleniem rzeczywistych procesów społecznych. Ich uczestnicy komunikują się ze sobą nawzajem, co prowadzi do tworzenia się opinii, ta zaś ma kluczowy wpływ na władzę. Przykładem tego, w jaki sposób internetowa rewolucja komunikacyjna zmienia świat polityki, jest blogosfera. Według Edwina Bendyka „blogi to część tej samej wirtualnej rzeczywistości, co światy wirtualne, i podobnie jak one zaspokajają potrzebę ekspresji i porozumiewania się. Ich potencjał [...] może być rzeczywiście rewolucyjny" ${ }^{2}$.Za ilustrację realnego wpływu blogerów na kształt polityki na wysokim szczeblu może posłużyć film Jamesa Rogana Wojna na blogach (Blog Wars, USA 2006), ukazujący, jak znaczny wpływ na scenę polityczną ma wymiana poglądów wśród społeczności internetowych ${ }^{3}$. Warto zastanowić się, w jaki zatem sposób politycy wykorzystują możliwość samodzielnego kreowania przestrzeni internetowej. Czym charakteryzują się pisane przez niech dzien-

E. Bendyk, Zrozumieć rewolucję, „Polityka” 2008, nr 2661, s. 6.

Tamże, s. 7.

http://www.cyfraplus.com.pl/program/abo/?full/26541 [dostęp: 28.02.2009]. 
niki? Jak można je ocenić, biorąc pod uwagę kryteria marketingu oraz komunikacji politycznej?

Internet stał się tak istotnym środkiem przekazu, że nie sposób prowadzić kampanii wyborczej ani utrzymywać wysokich wyników w sondażach bez odwołania się do niego. Posiadanie własnej strony internetowej oraz obsługa poczty elektronicznej jest już w polityce standardem. Istotnym elementem kreowania wizerunku jest obecnie blog. Nie należy traktować go jak propagandowej witryny partii, nie jest to także miejsce do publikacji programów partyjnych. Według Eryka Mistewicza najistotniejszą cechą internetowego pamiętnika jest to, by pisał go sam autor - nieautentyczność opublikowanych treści nietrudno wykryć. Blog polityka powinien także budzić emocje, aby zatrzymać czytelników. Odwołanie się do nowoczesnych środków komunikacji nie zastąpi bowiem ciekawych historii, które powinny zainteresować odbiorców i skłonić ich do dalszego zapoznawania się z ofertą wyborczą danego polityka ${ }^{4}$. Istotną cechą bloga mającego zapewnić autorowi polityczny sukces jest techniczna strona dziennika - jego szata graficzna, możliwości komunikacji (zarówno czytelników z autorem, jak i czytelników między sobą), jakie oferuje. Istotną, choć wielokrotnie niedocenianą kwestią jest wybór serwisu, w którym zamieszczony zostanie blog. Najpopularniejsze portale ułatwiające prowadzenie dzienników internetowych wchodzą w skład spółek, skupiających także inne środki przekazu. Treści przekazywane przez media należące do owych grup najczęściej wpisują się w określony światopogląd, co tworzy u odbiorców wizerunek danej spółki jako identyfikującej się z określonymi postawami. W przypadku nieprofesjonalnych blogerów wybór serwisu, a zatem określenie swojej identyfikacji światopoglądowej, nie ma kluczowego znaczenia, ponieważ - w przeciwieństwie do osób publicznych - nie podlegają oni nieustannej ocenie. W przypadku polityka wybór serwisu blogowego związanego z mediami o „niewłaściwym” profilu poważnie rzutuje na wiarygodność twórcy.

Blogi pisane przez polityków można podzielić w oparciu o oś prawicalewica, istnieją jednak również inne kryteria klasyfikacji: długość prowadzenia bloga, kontrowersyjność publikowanych treści, styl, w jakim utrzymane są notatki. Na podstawie takiej klasyfikacji można wyróżnić kategorię blogowych pionierów, do których można zakwalifikować Ryszarda Czarneckiego oraz Kazimierza Marcinkiewicza. Kolejną kategorią są blogerzyskandaliści, skupiający uwagę odbiorców publikowaniem kontrowersyjnych treści. Do kategorii skandalistów włączyć można Janusza Palikota i Joannę Senyszyn. Wąską kategorię stanowi blog sprawozdawczy, prowadzony np.

E. Olczyk, B. Waszkielewicz, Z dziennika leniwego polityka, „Rzeczpospolita” 20.08.2008, nr 194, s. A-005. 
przez Waldemara Pawlaka. Mimo zachowawczego stosunku do nowych mediów, na pisanie blogów zdecydowali się (z różnym skutkiem) również politycy uznawani za konserwatywnych, tacy jak Jarosław Kurski, Tadeusz Cymański i Wojciech Wierzejski. Niniejszy artykuł traktuje także o zjawisku, które zaistniało w polskim Internecie niedawno, o powstawaniu platform politycznych - rozbudowanych portali, skupiających wiele narzędzi komunikacji z odbiorcami.

\section{Blogowi pionierzy}

Pierwszym polskim politykiem, który zdecydował się na pisanie bloga, był obecny poseł Parlamentu Europejskiego, Ryszard Czarnecki. Notatka rozpoczynająca dziennik datowana jest na 20 maja 2004 r. Wybierając tę właśnie metodę dotarcia do odbiorców, parlamentarzysta wzbudził powszechne zainteresowanie - mimo że blog jako środek ekspresji był już popularny wśród polskich internautów, politycy nie dostrzegali oferowanych przezeń możliwości. Strona jest aktualizowana codziennie, co ma niezwykle istotne znaczenie dla blogów prowadzonych przez polityków - długie przerwy między poszczególnymi notatkami zniechęcają odbiorców oraz stwarzają wrażenie ich lekceważenia. Czarnecki zadbał także o odpowiednią długość publikowanych notatek. Z marketingowego punktu widzenia liczba użytych słów decyduje o utrzymaniu uwagi czytelnika - zbyt długi komunikat może go zniechęcić do ponownego odwiedzenia strony, zbyt krótki natomiast wygląda nieprofesjonalnie. Istotna jest także lokalizacja bloga - autor zdecydował się umieścić go we własnej domenie internetowej, co pozytywnie wpływa na spójność wizerunku oraz pozwala odbiorcom zapoznać się z innymi aspektami działalności parlamentarzysty zaprezentowanymi w Internecie. Ilustracją witryny jest także wideoblog, zawierający pliki multimedialne dotyczące zarówno samego polityka, jak i ważkich kwestii politycznych.

We wrześniu $2006 \mathrm{r}$. autor ogłosił, że „blog będzie równolegle dostępny na stronie internetowej i na "onecie»". Warto podkreślić, że portal Onet.pl wchodzi w skład grupy TVN, skupiającej media o profilu powszechnie uważanym za liberalny. Umieszczenie bloga w jednym z najpopularniejszych serwisów w Polsce prawdopodobnie miało na celu zwiększenie popularności dziennika i odniosło spodziewany skutek - dzięki intensywnej reklamie strona zanotowała niemal sześćset tysięcy odsłon. Przewaga Onetu nad prywatną domeną Czarneckiego polega również na możliwości dodawania komentarzy do poszczególnych wpisów. Polityk umożliwił także czytel-

http://ryszardczarnecki.blog.onet.pl/1,AR3_2006-09_2006-09-01_2006-09-30,index.html [dostęp: 10.03.2009]. 
nikom podejmowanie dyskusji oraz sygnalizowanie istotnych zagadnień, publikując na swojej stronie obszerne dane kontaktowe i zachęcając do skorzystania z nich: "Jeśli zechcecie Państwo wymienić ze mną poglądy, podzielić się swoimi uwagami i spostrzeżeniami lub powiadomić mnie o czymś - proszę pisać na adres e-mail..." ${ }^{6}$. Powyższe sformułowanie wyróżnia się na tle standardowych formularzy kontaktowych, zatytułowanych „napisz do mnie" i sprawia wrażenie osobistego zwrotu do czytelnika.

Debiutancka notatka z maja 2004 r. stanowi zapowiedź treści bloga autor rozpoczyna ją od komentarzy dotyczących kampanii wyborczej do Parlamentu Europejskiego, jednak porusza także tematy niezwiązane z polityką - pisze o kulinariach, kinie, wydarzeniach sportowych. Czarnecki prezentuje swoje spostrzeżenia, wybierając emocjonalny model przekazu - blog, choć publiczny, stylizowany jest na prywatny pamiętnik. Opisane zostają emocje związane z egzaminem maturalnym syna ${ }^{7}$, chorobą matki ${ }^{8}$, wizyty u lekarzy ${ }^{9}$. Każda z notatek zawiera jednak treści dotyczące tak bieżących wydarzeń politycznych, jak i wykonywania pracy eurodeputowanego. Utwierdza to czytelnika w przekonaniu, że każdy dzień autora wypełniony jest obowiązkami służbowymi, a zatem rzetelnie sprawuje on powierzoną mu funkcję. Czarnecki zwraca szczególną uwagę na rangę swoich zadań, bezpośredni kontakt z obywatelami oraz na wyrzeczenia, z jakimi się to wiąże: „Właśnie dowiedziałem się, że do końca miesiąca będę musiał dwukrotnie być w Brukseli. Najbliższy wyjazd odbywa się w najgorszym wariancie, wylot o świcie, powrót tego samego dnia nocą. A już następnego dnia lecę na szczyt gospodarczy Polska-Ukraina na Krym, który jest częścią szczytu politycznego Kwaśniewski-Kuczma”; „dziś ostatni dzień kampanii. Przedtem dolnośląski czworokąt: Kłodzko - Oława - Wrocław - Oleśnica. Żegnam się z wyborcami w czterech miastach, ale nie na raz bo - póki co - nie mam zdolności bilokacji”" ${ }^{11}$. Poseł stara się jednak zaprezentować opinię o polityce podzielaną przez wielu Polaków - zajmuje się nią, bo poczuwa się do takiego obowiązku, jednak zachowuje wobec niej dystans: „Dzwoni telewizja niemiecka ARD. Nie interesuje ich mój pogląd na temat integracji Europy i renegocjacji, ale pokazanie mnie w czasie meczu naszego klubu żużlowego. Mają rację. Zawsze mówiłem, że żużel jest ciekawszy niż polityka"12. Odbiorca może zatem od-

\footnotetext{
http://www.ryszardczarnecki.pl/pl/?page=kontakt [dostęp: 10.03.2009]. http://www.ryszardczarnecki.pl/pl/?page=blog_tresc\&id=2 [dostęp: 10.03.2009]. http://www.ryszardczarnecki.pl/pl/?page=blog_tresc\&id=28 [dostęp: 10.03.2009]. http://www.ryszardczarnecki.pl/pl/?page=blog_tresc\&id=31 [dostęp: 10.03.2009]. http://www.ryszardczarnecki.pl/pl/?page=blog_tresc\&id=30 [dostęp: 10.03.2009]. http://www.ryszardczarnecki.pl/pl/?page=blog_tresc\&id=22 [dostęp: 10.03.2009]. http://www.ryszardczarnecki.pl/pl/?page=blog_tresc\&id=3 [dostęp: 10.03.2009].
} 
nieść wrażenie, że dokładnie poznaje codzienne życie autora w jego zawodowych, a także ściśle prywatnych aspektach.

Spadek popularności polityków najczęściej wiąże się z mniejszą częstotliwością ich wystąpień w mediach masowych. W takich sytuacjach blogi mogą pełnić funkcję prywatnych środków przekazu, emitujących wyłącznie treści wybrane przez autora. Im bardziej owe treści są kontrowersyjne, tym większe prawdopodobieństwo, że zostaną one zacytowane przez media o dużym zasięgu - w ten sposób polityk zyskuje krótkotrwały rozgłos. Do takiego zabiegu uciekł się także Czarnecki, którego obecność w mediach uległa znacznemu ograniczeniu. Szczegółowe informacje o problemach zdrowotnych polityka oraz obraźliwa wypowiedź pod adresem byłego prezydenta Czech Vaclava Havla, poddającą w wątpliwość jego zdrowie psychiczne, wprawdzie zostały zacytowane w mediach, jednak popularność ich autora pozostała na niezmiennie niskim poziomie. Dziennik Czarneckiego, jako novum w polskiej polityce, z początku odgrywał istotną marketingowo rolę, pozwalając na nawiązanie bezpośredniego kontaktu z parlamentarzystą, zasygnalizowanie mu problemów, a także śledzenie jego działań. Warto zauważyć, że poczytność bloga jest ściśle związana z wysokimi notowaniami jego autora - gdy te spadają, internetowy dziennik, nawet prowadzony zgodnie ze standardami public relations, jest coraz rzadziej odwiedzany przez internautów i nie wywiera znacznego wpływu na wyniki sondaży.

Innym politykiem prezentującym własne opinie za pomocą bloga, nie zaś na łamach mediów, jest były premier Kazimierz Marcinkiewicz. Założył on własny dziennik internetowy już jako dyrektor Europejskiego Banku Odbudowy i Rozwoju, nie pełnił zatem oficjalnych funkcji w Polsce. Sytuacja ta rzutowała na styl wypowiedzi autora - obok komentarzy dotyczących bieżących wydarzeń znalazły się rozważania religijne, spostrzeżenia odnośnie do rodziny, notatki na temat sposobów spędzania wolnego czasu. Uwagi dotyczące polityki są utrzymane we wzniosłej (niejednokrotnie patetycznej) konwencji. Charakterystyczne dla Marcinkiewicza jest dostrzeganie analogii między szczegółami z jego życia prywatnego a zjawiskami społecznymi występującymi w większej skali, jak np. fala emigracji zarobkowej na Wyspy Brytyjskie. W przypadku mniej istotnych z punktu widzenia polityka tematów autor używa potocznego, nieformalnego języka. Ostatnie wpisy na blogu Marcinkiewicza mają stanowić przeciwwagę dla informacji dotyczących życia osobistego byłego premiera, publikowanych w tabloidach - polityk traktuje dziennik jak prywatną przestrzeń, w której zamieszcza sprostowania oraz listy otwarte do dziennikarzy. Według Janusza Czapińskiego styl obrany przez Marcinkiewicza ma na celu dotarcie do „młodych odbiorców, którzy dopiero uzyskali prawo wyborcze lub zaraz je uzyskają". Zdaniem psycholo- 
ga „ten blog to artyleryjskie przygotowanie do wyborów”,13. Były prezes Rady Ministrów nie określił wprawdzie, do zajęcia jakiego stanowiska prebendował, jednak bez wątpienia przypomniał wyborcom o swojej działalności.

Blog Marcinkiewicza stanowi przykład dynamiki zjawisk w Internecie - początkowo przyjęty entuzjastycznie, dziennik został poddany krytyce ze strony odbiorców. Śledząc zamieszczane tam treści, nietrudno dostrzec przyczynę publicystycznej porażki byłego premiera - są to niezbyt subtelne próby kreacji wizerunku, niespójnego $\mathrm{z}$ obrazem przedstawianym $\mathrm{w}$ mediach, a także z cechami osobowości, które próbował wyeksponować sam polityk. Blog nie stanowił dla niego dodatkowej możliwości nawiązania bliższego, niesformalizowanego kontaktu z wyborcami, lecz kolejny aspekt reklamy politycznej, która tym razem nie odniosła zamierzonych skutków.

\section{Blogerzy skandaliści}

Osobą, która potraktowała bloga jako element uzupełniający spójny wizerunek skandalisty, jest Janusz Palikot. Polityk, znany z kontrowersyjnych wypowiedzi oraz zachowań, umiejętnie wykorzystuje przestrzeń internetową do kreowania własnej postaci. Jego pytania są na ogół obliczone nie tyle na uzyskanie wyjaśnień, ile na zwrócenie uwagi na nadawcę komunikatu, a także na wskazanie niepożądanych zjawisk w życiu politycznym - zamieszczona na Poletku Pana Pe (nazwa bloga Palikota), obszerna relacja z kongresu Prawa i Sprawiedliwości w Nowej Hucie bez wątpienia miała na celu wypromowanie jej autora, który - jako polityk przeciwnej opcji oraz persona non grata w otoczeniu PiS - nie otrzymał zaproszenia na zjazd, a mimo to szczegółowo go opisał. Sprawozdanie stanowi jednak istotny - choć utrzymany w groteskowej konwencji - komentarz odnośnie do kondycji wspomnianej partii politycznej. Autor Poletka... wykorzystuje fakt, iż jest ono przestrzenią quasi-prywatną - popularność samego polityka oraz poczytność bloga zapewniają publikowanym na nim treściom szeroki odbiór, natomiast pojmowanie pamiętnika jako prywatnych zapisków upoważnia Palikota do zamieszczania sformułowań, których wystosowanie w parlamencie byłoby niemożliwe lub niezgodne z etyką poselską. Wypowiedzi posła niejednokrotnie balansują na granicy dobrego smaku, jednak sam autor zręcznie wykorzystuje zasadę licentia poetica, odwołując się do przynależności bloga do sfery nieoficjalnej.

Parlamentarzysta z rozmysłem zaplanował działania w Internecie. Powstanie dziennika poprzedziła kampania reklamowa, polegająca na umieszczaniu na billboardach w całym kraju neologizmów - takich jak: „cu-

${ }_{13}$ http://wiadomosci.onet.pl/1367300,11,item.html [dostęp: 10.03.2009]. 
dzogłupstwo”, „paplament”, „odkurzacz” (neologizm znaczeniowy) - oraz informacji o "godzinie zero", przypadającej pierwszego lipca 2007 r. Tego dnia o północy blog został oficjalnie otwarty ${ }^{4}$. Jak wcześniej wspomniano, zamieszczane na nim notatki utrzymane są w groteskowej, kpiącej konwencji, uznawanej przez wielu komentatorów za niegodną parlamentarzysty i stanowiącą nadużycie wolności słowa. Jak zauważa poseł Platformy Obywatelskiej Rafał Grupiński, „,blog Palikota to cena demokracji”. ogranicza się jednak do zapewniania sobie rozgłosu za pomocą skandalizujących wypowiedzi - prowadzi działania o wymiernych skutkach, o czym donosi na swoich stronach internetowych, powiązanych z blogiem. Odzwierciedlają one wizerunek parlamentarzysty, jednak są wyraźnie podzielone na sferę zawodową, w której szczegółowo zaprezentowano dokonania komisji Przyjazne Państwo, oraz nieoficjalną, stanowiącą płaszczyznę swobodnych wypowiedzi. Na obu stronach polityk zwraca się bezpośrednio do odbiorców, zachęcając ich do nawiązania ze sobą kontaktu - w witrynie komisji wyborcy mają możliwość zgłaszania „absurdów prawnych”"16 , natomiast na blogu mogą oni komentować wypowiedzi autora. Istotną wadą dotyczącą powyższej funkcji jest brak moderacji - nietrudno przewidzieć, że kontrowersyjne sformułowania sprowokują niewybredne komentarze. Usunięcie uwag składających się wyłącznie z wulgaryzmów nie wydaje się stanowić cenzury lub zamachu na wolność wypowiedzi, a znacznie podniosłoby poziom dyskusji. Odbiór bloga poprawiłaby także zmiana niezbyt estetycznej grafiki, natomiast jego prestiż wzrósłby, gdyby dziennik został przypisany do istniejącej już prywatnej domeny Palikota - umieszczanie go w bezpłatnym serwisie portalu Onet.pl być może wynika z egalitarystycznych pobudek oraz racjonalnego gospodarowania finansami, jednak w przypadku polityka o powszechnie znanym wysokim statusie majątkowym może być odbierane jako nieprofesjonalne.

W odróżnieniu od innych blogów prowadzonych przez polityków, dziennik Palikota nie służy zatem nawiązaniu bliższego kontaktu wyborców z parlamentarzystą oraz zgłaszaniu różnego typu postulatów - taką możliwość oferuje strona sejmowej komisji Przyjazne Państwo. Blog natomiast ma ubarwiać wizerunek swojego autora oraz zwiększać zainteresowanie mediów nim i jego działaniami. Zdaniem sowich przeciwników politycznych Palikot jest do cna skompromitowany, a jego obecność w mediach jednie ową kom-

14 http://mediafm.net/internet/11307,Blog-Palikota-juz-w-sieci.html [dostęp: 12.03.2009].

15 http://www.money.pl/archiwum/mikrofon/artykul/grupinski;blog;palikota;to;cena;demo kracji,115,0,313203.html [dostęp: 12.03.2009].

16 http://www.przyjaznepanstwo.pl/index.php?option=com_frontpage\&Itemid=1 [dostęp: 12.03.2009]. 
promitację pogłębia. Warto jednak za Janiną Paradowską zauważyć, że „Palikot ma tę przewagę [nad innymi politykami], że nie kłamie, a jeśli pyta, czasem nazbyt obcesowo, o różne sprawy, to raczej o takie, o które inni nie mają odwagi zapytać" ${ }^{17}$. Do zadawania owych pytań niejednokrotnie służy mu właśnie blog, dzięki któremu polityk wygrywa internetowe rankingi popularności, wyprzedzając Dalajlamę ${ }^{18}$.

Skandalistka z drugiego krańca sceny politycznej, Joanna Senyszyn, także wybrała blog jako środek ekspresji. Na jego łamach krytykuje tak obecny gabinet, jak i minione, opozycję oraz koalicję, przeciwników politycznych, którzy nie znaleźli się w rządzie bieżącej kadencji, a także księży i hierarchię kościelną. Wielokrotnie krytykuje także posła Palikota, zarzucając mu, że „wpadł w pułapkę eskalowania sensacji, którą sam na siebie zastawił" ${ }^{\prime 19}$. Blog Senyszyn nie odbiega jednak standardem od dziennika, który autorka krytykuje. Podobnie jak Palikot, posłanka piętnuje nieprawidłowości, takie jak obsadzanie wysokich stanowisk niekompetentnymi pracownikami lub marnotrawienie finansów publicznych. Ona także posługuje się groteską i ironią. Różnica między obojgiem autorów polega jednak na tym, że czytelników poszukujących ściśle merytorycznych treści poseł Platformy Obywatelskiej odsyła do strony swojej komisji sejmowej, Senyszyn zaś własne projekty ustaw zamieszcza na blogu, gdzie sąsiadują z uwagami dotyczącymi gwiazdy muzyki pop oraz życia prywatnego biskupów. Notatki publikowane $\mathrm{w}$ dzienniku zyskują setki, a $\mathrm{w}$ przypadku szczególnie kontrowersyjnej zawartości - tysiące komentarzy. Uwagi te, podobnie jak w przypadku Palikota, polegają bowiem na wymianie inwektyw między zwolennikami a zagorzałymi przeciwnikami autorki. Emocje wzbudzane przez kolejne wpisy nie dziwią - tematem najczęściej poruszanym przez Senyszyn jest funkcjonowanie Kościoła katolickiego w Polsce. Zważywszy na sposób prezentowania powyższego zagadnienia, trudno uniknąć przypuszczenia, że celem posłanki nie jest wyłącznie obrona idei neutralności światopoglądowej państwa.

Senyszyn wyraźnie określa swoją grupę docelową - zarówno przez poruszaną tematykę oraz sposób, w jaki przedstawia wybrane problemy polityczno-społeczne, jak i przez sam projekt graficzny bloga. Jaskrawoczerwony szablon strony, nawiązujący do barw lewicy, stanowi tło dla obszernych notatek dotyczących ważkich światopoglądowo zagadnień, wobec których w Polsce nieustannie toczy się nierozstrzygnięta debata - pozycji kobiet w

J. Paradowska, Garnitur z teflonu, ,Polityka” 2009, nr 2696, s. 16.

http://wiadomosci.wp.pl/kat,1342,title,Janusz-Palikot-wybrany-Czlowiekiem-Roku-

2008,wid,10914930,wiadomosc_video.html [dostęp: 12.03.2009].

http://senyszyn.blog.onet.pl/ [dostęp: 12.03.2009]. 
społeczeństwie, usuwania ciąży, eutanazji, zapłodnienia pozaustrojowego etc. Sama Senyszyn nie stara się o nadanie swoim wypowiedziom koncyliacyjnego charakteru, wyraźnie podkreślając swój światopogląd. Wyżej wymienione czynniki utrudniają jednak komunikację. Czytelnicy dzieleni są na tych, którzy się z autorką zgadzają i popierają jej postępowe idee, oraz na „katolicki, ziemniaczano-buraczany lud” ${ }^{20}$, co nie skłania do podjęcia rzeczowej dyskusji. Podobnie zatem jak w przypadku Palikota, blog nie służy nawiązaniu kontaktu oraz wymianie opinii między posłanką a odbiorcami, lecz promocji oraz kreacji wizerunku. Jego wyrazistość ma szczególne znaczenie w sytuacji rozbicia oraz utraty znaczenia politycznego lewicy - skandalizujący blog jest zatem niewyszukanym, choć skutecznym zabiegiem marketingowym.

\section{Blog sprawozdawcy}

Przeciwstawny wyżej opisanym styl prowadzenia bloga charakteryzuje dziennik Waldemara Pawlaka. Obok wspomnianych już Ryszarda Czarneckiego i Kazimierza Marcinkiewicza prezes Polskiego Stronnictwa Ludowego był jednym z pierwszych polityków, którzy wybrali tę metodę komunikacji. W regularnym zamieszczaniu nowych wpisów nie przeszkodziło mu także objęcie stanowiska wicepremiera i ministra gospodarki, czym zadziwił media - był wówczas, obok Carla Bildta - ministra spraw zagranicznych Szwecji, oraz Margot Wallstrom - wiceprzewodniczącej Komisji Europejskiej, jednym z nielicznych wysoko postawionych polityków prowadzących zapiski w Internecie ${ }^{21}$.

Blog Pawlaka nie jest dla polityka narzędziem intensywnej autopromocji, nie stara się on też kreować wizerunku sprzecznego z tym, który wyborcy znają z mediów. Nadmierna swoboda wypowiedzi publikowanych w Internecie byłaby niespójna ze zdystansowaną i powściągliwą postawą wicepremiera prezentowaną podczas kontaktów z dziennikarzami i współpracownikami politycznymi, relacjonowanych przez tradycyjne media. Poprzez wypowiedzi zamieszczane na łamach dziennika prezes PSL nie wywołuje skandali, lecz relacjonuje czytelnikom przebieg swojej pracy w rządzie. Wypowiedzi odnoszące się do podejmowanych zadań utrzymane są w iście sprawozdawczej, niewyszukanej stylistyce, jednak stanowią one rzetelną, regularnie uzupełnianą relację z wykonywanej pracy, docenianą przez wyborców. Blog zawiera także odnośniki do ciekawych artykułów prasowych lub

${ }^{20}$ http://senyszyn.blog.onet.pl/1,AR3_2006-09_2006-09-01_2006-09-30,index.html [dostęp: 12.03.2009].

$21 \mathrm{http} / / /$ pl.wikipedia.org/w/index.php?ns0=1\&search=blog\&title=Specjalna\%

3ASzukaj\&fulltext=Advanced + search\&fulltext [dostęp: 14.04.2009]. 
audycji radiowych z udziałem polityka, a także sprostowania odnoszące się do nieprawdziwych lub niepełnych (zdaniem autora) publikacji.

Decyzja o założeniu bloga prawdopodobnie została podjęta przez Pawlaka z myślą o dotarciu do nowej grupy wyborców - tradycyjny elektorat PSL to osoby, dla których Internet nie stanowi głównego źródła informacji oraz rozrywki. Zdaniem dziennikarza Łukasza Medekszy, współtwórcy bloga Piąta władza, ,pisanie bloga to ukłon w stronę ludzi młodych, korzystających na co dzień z nowych technologii, mieszkających raczej w dużych miastach" ${ }^{22}$, dotychczas niezwiązanych z partią agrarną. W 2006 r. ugrupowanie posłużyło się również hasłem „PSL - skuteczni dla młodych" ${ }^{\text {,3 }}$, co może świadczyć o próbie zmiany wizerunku stronnictwa.

Dziennik z pewnością spełnia swoje zadanie jako płaszczyzna „konwersacji politycznej" ${ }^{24}$ - autor dostrzega i wykorzystuje możliwości Web 2.0. Najbardziej aktywnie spośród wymienionych blogerów angażuje się w merytoryczne dyskusje z czytelnikami oraz zachęca ich do zamieszczania uwag. Polityk skrupulatnie odpowiada na komentarze czytelników, zaprasza też do kontaktu za pomocą poczty elektronicznej.

Treść bloga, jakkolwiek niewyszukaną, można uznać za poprawną. W kwestiach technicznych popełniono natomiast powszechne błędy, charakterystyczne dla polskich blogów politycznych. Dziennik zamieszczono w bezpłatnym serwisie - obniża to prestiż strony i zmusza do wybrania gotowego, nieestetycznego wzorca grafiki, co z kolei podważa profesjonalizm autora (pasjonata nowych technologii ${ }^{25}$ ). Projekt strony w najlepszym przypadku można uznać za purystyczny, a pojawiające się na niej reklamy utrudniają odbiór bloga ${ }^{26}$ oraz nie licują z wizerunkiem polityka. Warto jednak zauważyć, że dziennik Pawlaka, choć wizualnie nieatrakcyjny oraz niezawierający humorystycznych lub skandalizujących treści, stanowi wzorowy przykład wykorzystania tego narzędzia do skutecznej komunikacji z wyborcami.

\section{Blogi konserwatystów}

Możliwości dotarcia do własnego elektoratu oraz pozyskania nowych zwolenników dzięki Internetowi w znikomym stopniu wydają się dostrzegać czołowi politycy Prawa i Sprawiedliwości. Choć w 2007 r. Jacek Kurski twier-

\footnotetext{
http://5wladza.blogspot.com/2006/08/waldemar-pawlak-zaoy-bloga.html, [dostęp: 13.03.2009].

http://www.psl.org.pl/?p=historia, [dostęp: 16.03.2009].

http://www.blogger.com/profile/18238413633502219031, [dostęp: 16.03.2009].

http://pl.wikipedia.org/wiki/Waldemar_Pawlak, [dostęp: 13.03.2009].

http://mediacafepl.blogspot.com/2006/08/pawlak-otwiera-blog-na-onecie.html, [dostęp: 13.03.2009].
} 
dził, że partia „wyciąga wnioski z ostatnich wyborów, kiedy sporo młodzieży zagłosowało przez pomyłkę nie na nią" oraz obiecywał, że członkowie PiS „będą bardziej komunikatywni”, a portal Money.pl informował o powstaniu wideobloga Jarosława Kaczyńskiego oraz o internetowych dziennikach czołowych działaczy ugrupowania ${ }^{27}$, politykom zabrakło wytrwałości. Dziennik Kurskiego zawiera osiem notatek, z których ostatnia pochodzi z października 2007 r. Wpisy dotyczą głównie przeciwników politycznych oraz nieprawidłowości, których się dopuścili, działając na szkodę PiS. Blog nie zawiera żadnych merytorycznych informacji, rzeczowych komentarzy, powołujących się na wiarygodne źródła - stanowi zbiór oskarżeń oraz inwektyw. Możliwość odniesienia się do nich jest znikoma - z powodu błędu technicznego zamieszczone pod notatkami komentarze zamieniają się w ciąg bezładnych znaków, natomiast poziom niemoderowanych wpisów w księdze gości nie zachęca do dyskusji.

Blog oferuje zatem minimalne możliwości nawiązania kontaktu $\mathrm{z}$ autorem, a przez to komunikacji, wymiany poglądów lub zgłaszania problemów i zadawania pytań. Ponadto stwarza wrażenie nieprofesjonalnego - nie jest przypisany do domeny internetowej macierzystej partii autora, a umieszczenie go w bezpłatnym serwisie portalu Wirtualna Polska powoduje wyświetlanie się krzykliwych reklam. Kurski prowadził dziennik jedynie przez miesiąc - brak wytrwałości oraz entuzjazmu w stosunku do tego przedsięwzięcia pozwala zatem przypuszczać, że nie wynikało ono z inicjatywy samego posła, lecz było odpowiedzią na odgórne zarządzenie dotyczące zmiany wizerunku partii.

Podobne wrażenie stwarza blog innego posła PiS, Tadeusza Cymańskiego, prowadzony między lutym a kwietniem 2008 r. Notatki, podobnie jak w przypadku Kurskiego, także zawierają zarzuty o nieprawidłowe sprawowanie władzy, skierowane do Platformy Obywatelskiej, oparte jednak na wiarygodnych informacjach i stanowiące komentarz do przytaczanych faktów, nie zaś zbiór niczym nie popartych hipotez. Wpisy są utrzymane w konwencji przemówień wygłaszanych na trybunie sejmowej - zbyt długie wypowiedzi, zdania wielokrotnie złożone oraz homeryckie porównania nie zatrzymują uwagi czytelnika. Niewielkie zainteresowanie treścią bloga odzwierciedla liczba komentarzy oraz wpisów w liście gości - w przypadku blogów Palikota lub Czarneckiego ilość uwag sięga ponad tysiąca, na temat notatek Cymańskiego wypowiada się kilkunastu czytelników. Autor bloga nie kieruje swoich wypowiedzi do odbiorców, lecz formułuje uniwersalne sądy moralne lub zdecydowanie odcina się od odpowiedzialności za bieżącą sytu-

27 http://news.money.pl/artykul/kaczynski;ma;swoj;videoblog,202,0,308426.html [dostęp: 13.03.2009]. 
ację polityczną. Na stronie Cymańskiego to nie osoba autora ani jego opinie są kluczowe, lecz partia, do której należy. Polityk w swoich wypowiedziach posługuje się utartymi wzorcami wypowiedzi, natomiast odnoszące się do nich komentarze stanowią przykłady skrajnych reakcji - od wulgaryzmów po bezkrytyczne pochlebstwa. Podobnie zatem jak w przypadku bloga Kurskiego, parlamentarzyście nie udało się stworzyć płaszczyzny komunikacji. Rezygnacja z publikowania dalszych treści po dwóch miesiącach od zaistnienia strony również świadczy o jej niewielkiej skuteczności w docieraniu do tradycyjnie usposobionego elektoratu.

Mimo niepowodzeń Prawa i Sprawiedliwości blogi prowadzone przez polityków o światopoglądzie konserwatywnym mogą zyskać popularność wśród internautów, o czym świadczy dziennik Wojciecha Wierzejskiego. Choć Liga Polskich Rodzin w 2007 r. nie osiągnęła progu wyborczego, a jej obecny przywódca rzadko występuje publicznie, jego blog - niegdyś źródło kontrowersyjnych opinii cytowanych w serwisach informacyjnych - nadal odwiedzają setki czytelników ${ }^{28}$. W pierwszej notatce, opublikowanej we wrześniu 2006 r., autor uzasadnia założenie strony oraz prezentuje swoje cele. Wierzejski rzetelnie relacjonuje przebieg swojej pracy oraz opisuje działania podejmowane do $2007 \mathrm{r}$. w parlamencie przez LPR oraz innych członków koalicji. Polemizuje przy tym z politykami innych opcji lub komentuje bieżące wydarzenia, najczęściej opierając się na wiarygodnych źródłach informacji. Konsekwentnie przedstawia przy tym własne poglądy, ilustrując je licznymi przykładami, również zaczerpniętymi z własnego życia. Wierzejski, będący w 2006 r. osobą publiczną, porusza tematy takie jak kara śmierci, prawa mniejszości (w tym mniejszości seksualnych), relacje polskoniemieckie, odnosząc się do powyższych kwestii w radykalny sposób. Znany $\mathrm{z}$ wierności swoim poglądom polityk nie zadbał jednak o ich obronę, co może sprawiać wrażenie lekceważenia odbiorców. Obszerne, regularnie publikowane notatki dotyczą kwestii ważkich dla potencjalnego elektoratu LPR, jednak ów elektorat systematycznie maleje, a dziennik zawierający kategoryczne, jednoznaczne stwierdzenia o skrajnie prawicowym charakterze nie przyczynia się do jego zwiększania.

Strona techniczna bloga jest poprawna - minimalistyczna grafika ułatwia odbiór treści, czytelne odnośniki do archiwum oraz pokrewnych witryn internetowych pozwalają na sprawną nawigację, natomiast obszerna notka biograficzna - rzadko występująca w pamiętnikach polityków - pozwala na szczegółowe zapoznanie się z działalnością oraz osiągnięciami autora. Warto jednak zwrócić uwagę na lokalizację bloga. Jakkolwiek w przypadku innych

${ }^{28}$ Szacunki na podstawie liczby zamieszczanych komentarzy oraz licznika odwiedzin. 
polityków umieszczanie dzienników w bezpłatnych serwisach, szczególnie w serwisie portalu Onet.pl, można uznać za niezręczność, przywódca LPR, postępując w ten sposób, dopuścił się rażącej niekonsekwencji. Zajadła krytyka liberalizmu nie przeszkodziła mu w korzystaniu z popularnego, cieszącego się dużą liczbą odwiedzin portalu. Próba pozyskania jak największego grona czytelników jest zrozumiała, jednak odstąpienie od ostentacyjnie wyznawanych zasad znacząco obniża spójność wizerunku oraz wiarygodność polityka.

Blog Wierzejskiego jest narzędziem przekazywania poglądów autora trudno nazwać ów proces komunikacją, ponieważ kluczowe jest tu nadanie przekazu, natomiast pomija się kwestię jego odbioru oraz informacji zwrotnej. Dziennik pełni także funkcję zastępczą wobec mediów masowych, w których wzmianki dotyczące polityków LPR pojawiają się sporadycznie. Regularne aktualizowanie strony stanowi komunikat dla elektoratu - choć partia nie znalazła się w parlamencie, nadal funkcjonuje.

\section{Uwagi końcowe}

Twórcy polskich blogów o tematyce politycznej szybko dostrzegli możliwości, jakie oferuje Web 2.0. Samodzielne kreowanie wirtualnej przestrzeni zyskało wielu zwolenników, początkowo wykorzystujących tę możliwość jako formę osobistej ekspresji i refleksji.

W związku z coraz większą liczbą użytkowników Internetu i wzrastającą popularnością serwisów blogowych również politycy dostrzegli w nich narzędzie pozwalające skuteczniej dotrzeć do elektoratu. Dzienniki stały się elementem urozmaicającym kampanię wyborczą, przybliżającym sylwetkę polityka wyborcom i pozwalającym na bieżąco śledzić jego poczynania. Ważnym aspektem podejmowania działań marketingowych w sieci jest możliwość dotarcia do wielu odbiorców w krótkim czasie przy niewielkim nakładzie pracy oraz środków finansowych.

Istotnym czynnikiem wpływającym na jakość bloga jest - co może wydawać się paradoksem w przypadku pamiętnika - dobrowolność oraz samodzielność jego tworzenia. Dla polityków, którzy zaczęli prowadzić dzienniki w Internecie, ich aktualizacja staje się obowiązkiem, któremu nie zawsze są w stanie sprostać - notatki pojawiają się wówczas nieregularnie lub nie zawierają istotnych treści. Blogi uzupełniane przez osoby inne niż sam autor (asystent, sekretarka, współmałżonek) ${ }^{29}$ stają się bezosobowe i pozbawione emocji, co w niedługim czasie zniechęca czytelników. Warto podkreślić sposób, w jaki przebiega linia podziału między użytkownikami polskiego In-

${ }^{29}$ D. Uhlig, Marcinkiewicz pisze pamiętnik w Internecie, „Gazeta Wyborcza” 1.08.2006, nr 178, s. 6. 
ternetu - jakkolwiek w przypadku blogerów niezwiązanych zawodowo ze sprawowaniem władzy dominują dzienniki o profilu prawicowym, charakteryzują się one także większą wartością merytoryczną, tak wśród polityków występuje zjawisko odwrotne. Posłowie ugrupowań innych niż prawicowe wydają się przywiązywać większą wagę do nieformalnych metod docierania do wyborców. Może to być podyktowane większą liczbą użytkowników nowych technologii wśród osób w młodszym wieku, o liberalnych poglądach. Niezależnie jednak od preferowanego światopoglądu polscy politycy nadal wydają się nie doceniać skuteczności oddziaływania na odbiorców za pośrednictwem Internetu. W sytuacji, w której komercyjni reklamodawcy przeznaczają coraz większe fundusze na promocję produktów w sieci, zadziwiający jest brak zaufania oraz niechęć do wykorzystywania możliwości Web $2.0 \mathrm{w}$ reklamie politycznej. 


\section{Abstract}

The aim of the article is to present the importance of the Internet in political marketing. The author concentrates on the possibilities of the promotion of politicians based on the advantages of Web 2.0. The "second version" of the World Wide Web gives the democratic possibility of creating its content to each of its users. An important aspect of this phenomenon are weblogs (or simply blogs), primarily used as a manner of self-expression, evolving into a network of private websites dedicated to achieving individual aims. Technical possibilities offered by blogs enable the politicians to create their image, not demanding serious financial or professional investments.

The author analyses the blogs of Polish politicians in categories of political marketing. Amongst the criteria of analysis there may be found: the length of published posts, the controversies they evoke, the style of the remarks constituting the blogs. The authors of the blogs are divided into several categories, including blogging pioneers, scandalists, reporters, right-wing bloggers. Although the most popular blogs attract young internauts and are the source of citations for journalists, their content is based mainly on scandalous information or rhetorical questions, the aim of which is to irritate the opponents. The layout and the manner of writing of right-wing politicians indicate their target groups - blogs are certainly not the principal channel of communication between the politicians and their electorate. This may be explained by its structure - conservative voters seem more traditional and promotion in the Internet does not play significant role for them.

Although the advertisement in the Internet becomes the main field of interest of commercial companies, Polish politicians do not seem to recognise the importance of communicating their message in the Web. Polish spin doctors still do not appreciate the effectivity of modern technologies, which may be considered as surprising in the context of their development. 